\title{
Reconstructing the African Commons
}

A paper prepared for presentation at the Eighth Biennial Conference of the International Association for the Study of Common Property [IASCP] entitled 'Constituting the Commons: Crafting Sustainable Commons in the New Millennium', to be held at Indiana University, Bloomington, Indiana, USA,

May 31-J une 4, 2000

By

\author{
Liz Alden Wily \\ Political scientist and rural development specialist \\ P O Box 68228, Nairobi, Kenya
}

Tel: [254 2] 521596 Fax: [254 2] 252456 E-mail: lizwily@net2000ke.com

\section{Abstract}

A prominent socio-political trend in sub-Saharan Africa at the turn of the century is the development of new land tenure statutes. In general, these are intended to both reflect and promote changing property relations with strong directions towards increasing a market in land and to give statutory form to unregistered rights. Most of these rights arise and are maintained through customary regimes. In the process governments are being forced to determine the legal future of common property, a central construct of customary tenure. These include untitled commonage widely existing throughout the rural areas of Africa, often deemed 'public lands' with the implication of open access inherent. Attention is also being directed towards those conservation estates which governments have steadfastly secured to themselves [Forest and Game Reserves].

In the meantime, a less pronounced series of adjustments are occurring in the laws of governance and state-people relations, with a trend towards further devolution and the strengthening of institutions at the local level. Frequently this is being driven or supported through the crafting of new Constitutions towards greater democratisation on the one hand and more profound recognition of social and property rights on the other. Emerging empowerment of local communities, beginning to be endowed with more governance powers, is playing an important role, helping to shift the tenurial focus from state to people, from centre to periphery.

This paper examines these socio-legal developments with a view to assessing how rural commons in East and Southern Africa are being affected. The study draws upon tenure changes in twelve states; Kenya, Tanzania, Uganda, Malawi, Mozambique, Zambia, Zimbabwe, Namibia, Botswana, Swaziland, Lesotho, and South Africa.

The conclusion drawn is that, intentionally or otherwise, rural commons in the region are gaining a great deal more recognition than was anticipated during the $20^{\text {th }}$ century 
and will become a prominent property construct during the new millennium. The gain derives mainly from resigned recognition of the persistence of customary rights in land, despite decades of largely conversionary tenure processes aimed to extinguish customary regimes, and the need to now provide for these rights in national law. In the process, there is growing recognition of the utility of certain customary norms in tenure, not least being the capacity to hold property in common. For the fact remains that a good number of estates in land - and forests, wildlife and pastoral range prime among them - remain as unsuited to subdivision and individualisation in the $21^{\text {st }}$ century as they were in the $20^{\text {th }}$ century. Nor has appropriation of these properties by the state has not proved as successful as anticipated and development strategies look increasingly to the local level for reprieve.

Through these factors, notions of tenure are themselves undergoing transition at the turn of the century. A central development is the emergence of a new statutory tenure forms which permits groups of people to hold property in common in registrable ways and in ways which new laws are beginning to suggest as equivalent to entitlement of individually-owned estates. This development is the focus of this paper. The paper closes with a reflection of these changes in one prominent sphere of common property in the region; forests and woodlands. New forest law, it is shown, is beginning to provide for community-based tenure of these resources. This realised in a highly tangible way the quite dramatic change in fortunes of a long-existing practice in the continent, the right to hold estates in common. 


\section{THE STATUS OF COMMON PROPERTY IN THE LATE $20^{\text {TH }}$ CENTURY}

Common property has not fared well in East and Southern Africa over the last century. For all intents and purposes it has been in steady demise, both as a class of property and as a notion as to how land may and may not be held in statutorilybinding ways. ${ }^{1}$

Three forces have been apparent. The first is that complex of factors integral to the social transformation that has occurred in the region this century, through the penetration of capital, nation-making, and the overall 'Europeanization' of precapitalist African society. A critical element has been the steady commoditisation of property that accompanies such modernization.

Second, aligned to this has been the consistent thrust of colonial and postIndependence tenure ideology and programmes towards the individualisation of landholding, realised through European modes of entitlement, and concomitant failure to make statutory provision for the incidents or exercise of non-European regimes of landholding, including a failure to provide registrable commonhold entitlement. 'Customary' African tenure as a whole has been held in weak regard, and the holding of lands in common especially. This has been oftentimes misunderstood as a regime not of tenure at all, but of access, and worse, one with no socio-spatial boundaries - that is, a regime of open, or public, not private access.

Third, has been the steady appropriation of many of the most valuable local common properties by the state and their redesignation as state or government lands. This has been undertaken on the assumption that the state is the only proper guardian of such properties and the rightful primary beneficiary of their values [such as timber, wildlife and tourist values] and often on an assumption that these same properties are in any event, weakly tenured at best. Through this process alone, many millions of hectares of prime common property in the region has been lost to citizens, and particularly those who are hunter-gatherers, pastoralists or simply, the remote rural poor.

The effects of all the above have been considerable. Customary rights in land including those in which property is held in common at local group, community or tribal levels - have for most of the last century been tolerated rather than provided for, and admitted into national statutes only in the most permissive of terms. The general expectation has been that over time, through market forces, or with the help of programmes of tenure conversion, these rights and the regimes which sustain them would disappear, absorbed into 'modern' statutory forms, and those providing absolute and individual rights in particular.

In the interim, the vast, majority spheres of unregistered African landholding were to be afforded a blanket protection cum supervision of sorts through their designation 'native reserves', homelands, or later, 'trust lands' [Kenya], 'customary lands' 
[Malawi], 'communal lands' [Zimbabwe, Namibia] or simply public lands [Uganda, Tanzania, Rwanda]. Whereas in the past, this construct of 'virtual government lands' could be seen (at its most positive) as a function of misplaced colonial beliefs surrounding the nature of traditional rights in property, its persistence after Independence is less excusable. This has been most severely the case in Zimbabwe, Kenya and Namibia. In all these states, post-Independence Governments have chosen not to recognise local lands as owned by their inhabitants but have vested their ownership in the state or Presidents. Customary owners, individually, as households or as communities, occupy and use their own property as but tenants of state, their property directly vulnerable to reallocation for other purposes.

Thus in Zimbabwe, for example, the Tribal Land Act of 1979 was repealed after Independence in favour of a Communal Lands Act of 1982, which not only vested ownership of customary lands in the President, but dropped the proviso that he holds these in benign trust for the inhabitants of these lands [section 4]. As a consequence, local tenure amounts to no more than permissive occupancy - and strictly for residential and agricultural purposes [s.7-8]. Rights to occupy and use land such as forests or pasture or to hold these in common is simply not availed by the Communal Lands Act [s. 9]. ${ }^{2}$

In Namibia, the first Constitution of 1990 declared all untitled lands owned by the state [Schedule $5(1)$ ], and has recently entrenched, rather than removed, the principle in its National Land Policy, 1998 [s. 3.1], and the recently promulgated Communal Land Reform Act, 2000 [s. 17(1), February 2000]. Unlike Zimbabwe, these laws at least emphasise the trusteeship function of the state, a declaration not present in the original Constitution of Namibia. Again, recognition that land within these spheres may be held in common in registrable ways, is not provided.

In Kenya, the 1961 Constitution and subsequent Trust Land Act restructured a long-existing arrangement in which ownership over customary 'native' and now 'trust' lands was vested in County Councils. ${ }^{3}$ The central state established itself as the agent for those councils in matters of land. ${ }^{4}$ County Councils were endowed with the right to set aside and reallocate any part of these lands for more or less any purpose they saw fit, a capacity also granted to the central state for even less specific 'purposes of Government'. ${ }^{5}$ A good deal of land has been lost in this manner for both private end use, and for the use of these same lands for settlement schemes and the creation of Government and parastatal agricultural, livestock, timber extraction and other enterprise. ${ }^{6}$

\footnotetext{
2 Section 6 emphasises the right of the President (or by delegation, his Minister and Government) to remove any part of Communal Land into the class of State Land, or to reallocated in leases [s. 9-10] or any other purpose, albeit with 'consultation' with the local district council, which nonetheless has not right of veto. Inhabitants may be evicted [s.10(3)], if provided with other land or compensation for what is frankly described as 'such dispossession or diminution' [s. 12]. The District Council is availed powers to regulate and control settlement in Communal Lands [s. 13]. The right to object to dispossession, or to appeal to the courts, is not provided.

Commenced in 1939 and given new title and revised in 1961 at Independence.

Section 115 (2) of the Constitution, Cap. New Constitution, 1969 (revised 1998) and Section 53 of The Trust Land Act, Cap. 288.

5 Sections 116-118 of Constitution and sections $7 \& 13$ of Cap. 288.

$6 \quad$ As documented in Alden Wily with Mbaya, op cit.
} 
A main purpose intended and implemented in the following forty years has been to transform customary rights into statutory freeholds, through a programme of compulsory adjudication and entitlement. Even this supposedly benign intent has resulted in considerable loss of property of especially the poor, and prominently including lands held in common, generally subdivided in the process. The fate of vast pastoral lands has been similar, even although initially a special law was promulgated to enable parts of these lands to be held through group entitlement. ${ }^{7}$

In South Africa, the Bantustan/homeland construct was but a more severely exercised version of all the above; since the 1930 Native Land Acts, some millions of customary landowners have occupied and used these lands only by an increasingly notorious 'Permission to Occupy' [PTO], which could be (and frequently were) withdrawn at any time [DLA, 1997, Ntsebeza, 1999]. As described later, decision as to their future remains undecided.

Meanwhile, lesser populations have found themselves simply occupying lands directly designated as those of the state [Government, State or Public Lands]. This has most prominently affected societies who do not use or hold land in ways admitted into either majority African or European tenure regimes and who, for the lack of comparable tribal leadership, failed in the first instance to be regarded as tribes. Hunter-gatherers and pastoralists have been most affected - two groups in the region who own and regulate property in distinctive and almost entirely communal ways. Those who have not lost their property in its entirety, occupy Government land or land belonging to others in the most tenuous of ways. Needless to say, a great deal of prime forest, wildlife-rich and pastoral commonage has been subsumed in this manner. ${ }^{8}$

Thus, through all these mechanisms, common property has tended to be reviled, undermined, and ill-provided for and to exist variously in Government Lands or in virtual Government Lands as above. For all this, it has continued to exist, as has its regulatory framework - informal 'customary' regimes.

7 Reference is made here to the Land (Group Representatives) Act, Cap. 287, enacted in 1968, to enable pastoralists to convert their common land ranches, owned by elected representatives of the registered members of the group. Some 302 group ranches created but their subdivision was ordered by the President in 1979. Many poorer pastoralists did not find their names of the registers of members and many non-pastoralists have been found on the registers, generating considerable dispute and litigation, in no case yet resolved to the satisfaction of those pastoralists who claim to have been dispossessed. Alden Wily \& Mbaya, op cit. document example cases.

Short reference may be made here to the fate of San Bushmen in Botswana, for example, who lost all but a tiny proportion of their lands to its incorporation into state or tribal lands, and whose most recent eviction from the Central Kalahari Reserve to make way for wildlife interests, was perfectly legal, despite this Reserve having been created in the first instance by the late colonial Government ofr their protection; Ng'ong'ola, 1997, Luhling, 1998. Reference might also be made to the fate of Batwa Pygmies in Uganda, Rwanda and Zaire, none of whom have been afforded tenure over their ancestral forest lands; Luhling \& Kenrick, 1998, Alden Wily \& Kabananukye, 1996. Loss of Barabaig pastoral lands in Tanzania is amply reported upon by Naimir-Fuller, Maryam, Lugando et al. 1994, of Maasai pastoral lands by Shivji \& Kapinga, 1997 and Mustafa, 1997, and of the lands of Hadza hunter-gatherers by Handby, 1999. The untenured fate of pastoral lands in the Horn is well covered by Rahmato, forthcoming and Shazali \& Ahmed, forthcoming. 
Frustration with the failure of time, neglect, the market and individualisation and titling programmes to see the end of customary regimes, represents one of the impeti towards national land law reform in East and Southern Africa at this point in time. $^{9}$

There have of course been other prompts and the strongest of which has been the substantial socio-political change occurring in the region in the last decades of the $20^{\text {th }}$ century, through either new Independence, the ending of civil war, or the establishment of significantly new political regimes [Eritrea, Uganda, Rwanda, Zambia, Malawi, Mozambique, Namibia, South Africa, Zimbabwe, Mozambique]. As the most important asset of agrarian society, new perceptions and strategies as to the character and distribution of land rights are central to these changes - although, with the possible exception of Ethiopia, in not a single case has a nation state launched reform with redistribution towards equity its main or single objective. Nonetheless, in those countries where much African property has been lost through racially-discriminatory laws of the last century, restitution and related redistribution has been a leading motive in land reform [Zimbabwe since 1980, Namibia since 1990, and South Africa since 1994], much as it was an objective in the earlier land reforms of Kenya and Swaziland. The much wider thrust in the region towards increasing the security of unregistered rights is also expected to indirectly assist equity in property, through slowing down, if not halting, continuing polarisation in rural landholding and rising landlessness [Alden Wily, 2000a].

In some states, the main catalyst has been a simple matter of administrative and legal impatience with the inadequacies of what have been for the most part, laws adopted more or less wholesale from their colonial predecessors (whether English, Roman-Dutch, Italian, Portuguese or Belgian), and their failure to perform in ways expected or now needed by modern states. ${ }^{10}$ In most cases, shifts in socio-political relations between state and civil society have given a particular shape to points of dissatisfaction, prompted variously through the demands of multiparty-ism and heightening popular voice and demand. ${ }^{11}$

Tenure reform at the turn of the century does not exist therefore in either strategic or legal isolation. Socio-legal change is occurring in a host of sectors. New local government laws are being promulgated in half the countries of the region, without exception strengthening devolution and sometimes below the district level [Zimbabwe, Rwanda, Uganda, Tanzania, Mozambique, South Africa]. New National Constitutions have been promulgated since 1990 in Mozambique, Namibia, Zambia, Malawi, Ethiopia, Lesotho, Uganda, Eritrea and South Africa. The much older Constitutions of Tanzania, Kenya, Zimbabwe and Swaziland are themselves suddenly

\footnotetext{
9 A detailed overview of land reform in the sub-region is provided in Alden Wily with Mbaya, op cit. Chapter One, and an overview in Alden Wily, 2000a.

Refer McAuslan, 2000 forthcoming for review of the 'diaspora' of European law through colonial and post-colonial processes.

Alden Wily with Mbaya op cit. Chapter One, provide a detailed account of the history of current land reform in the countries covered in this paper. Alden Wily, 2000a provides an overview of the changing process of land reform towards greater democratisation.
} 
under review. Whilst couched in the declamatory language that has come to be expected from constitutional law, these embed critical relational changes such as the reform of judiciaries - directly helpful to matters of tenure given the frequent preponderance of land disputes in civil litigation. ${ }^{12}$ Reform is also occurring in natural resource sectors with virtually all countries in the region adopting new environmental management laws, indubitably spurred on by the international protocol culture of the 1990s. ${ }^{13}$ New wildlife, water, and forest laws are being drafted in almost as many states, as later described in the case of forestry.

Cumulatively, these developments signal important socio-political transitions at the turn of the century of which shifts in property relations are but one part, albeit one expected to be pivotal to further 'democratisation' of society in coming decades. Their impact upon the recognition of the existence of common property in the region, and provision for its support, is immense.

\section{A wave of statutory land reform}

Before turning to that central subject, a further background note is in order as to the context in which this is occurring.

The extent of the basic reform in property relations and law in sub-Saharan Africa is considerable. ${ }^{14}$ In Eastern and Southern Africa it is in fact only those states currently at war with themselves or others which have not embarked upon directive change in this area. In Uganda, Tanzania, Mozambique, Zambia, Eritrea, Namibia and South Africa, important new basic land tenure laws have been promulgated in the last decade, most of which are in only the earliest stages of implementation [TABLE 1]. Rwanda, Malawi, Lesotho, Swaziland, Zimbabwe and Swaziland have all begun to draft new National Land Policies, expected to lead to comparable law reform in the very near future. Even Kenya, the site of arguably the most dramatic tenure transformations to date, has finally found its current land law and administration seriously wanting and recently fielded a Presidential Commission of Land Law Inquiry [November 1999].

\section{Common concerns}

Commonality in the concerns of these reforms is striking. For if the initial agenda of each state has proved unique, certain common problems as quickly surface and are having to be addressed. These generally include the following -

how far should land itself, and powers over land, be vest in the state?

how far should a market in land be permitted and prompted - and how freely should land be available to non-citizens?

12 Observed with statistics for example, in respect of Kenya by the Eighth National Development Plan, in respect of Lesotho, by Kasanga, 1999.

13 A main task of these laws is to embed national protocols in national laws and also to establish environmental coordination agencies as agreed in some protocols. This has been achieved for example through the National Environment Statute, 1995 of Uganda, the Swazi Environmental Authority Act, 1992, the Environmental Framework Law, 1997 of Mozambique, and the Environmental Management and Coordination Bill, 1999 of Kenya.

14 Refer Toulmin \& Quan [eds.] forthcoming for an up-to-date collation of cases in sub-Saharan Africa. 
at what level of society and with what degree of autonomy from the executive, should property relations be regulated and administered, and with what extent of popular participation?

how may the plethora of land disputes be more swiftly and fairly disposed with?

how should the rights of women in land be handled, a sector of society illserved by both customary and European tenure law but now definitively the most important productive force in agriculture?

how far should the rights of long-term farm-workers and tenants be made rights of ownership or otherwise secured?

how far should minority land use and tenure regimes [hunter-gatherers and pastoralists] be recognised?

how should the occupancy of the still-growing millions of urban untenured poor, thus far designated as illegal squatters, be dealt with?

how may all rights in land be brought into a simple, efficient, accessible and easily maintained system of documentation and evidence?

how may the budgetary implications of tenure change be minimised without putting the implementation of reform at risk? How much can the user afford to pay?

And, central to reform and to our discussion here -

how should unregistered, customary landholding be dealt with in the law?

how should commonage and common rights in land be regarded in the law?

\section{Common response}

Whilst response thus far has been uneven and country-specific, a notable degree of commonality in response is emerging. Typically, certain matters are receiving less or more attention in the early stages of reform. Gender issues, for example, are receiving a good deal attention that initially espoused, Tanzania excepting. ${ }^{15}$ Nor has the land security of hunter-gathers, or pastoralists in the north-east of the continent benefited thus far from new tenure legislation, again with the exception of Tanzania. ${ }^{16}$

In contrast, the security of long-standing farm workers and tenants has been much attended to [South Africa, Uganda]. ${ }^{17}$ Significant progress has also been made in respect of the untenured urban poor who have steadily increasing opportunities of moving from their status as illegal squatters to tenured occupants, and sometimes through quite innovative mechanisms - notably

15 The trend has been for the issue to receive considerable attention at the point of policy formulation, partly through activist lobbying, but for this not to be carried through into new tenure law [Uganda, Mozambique, South Africa]. So far only the new tenure laws of Tanzania provide for a presumption of espousal co-ownership of the household's primary residential and agricultural property. Elsewhere this is being offered as only an opportunity. Failure to deliver positive support for female rights in land is a current source of major contention in Uganda. For a review of genderrelevant tenure provisions in new land law, refer Alden Wily with Mbaya, op cit. Chapter One.

${ }_{16} \quad$ Provisions for pastoral rights in land detailed in Alden Wily with Mbaya, op cit. More understandably, given their tiny numbers, hunter-gatherers in twelve states, are yet to see direct recognition of their rights in new law.

17 In Uganda, tenants may acquire a Certificate of Occupancy which gives them more or less all rights in the land excepting its ownership and gains the first right of refusal should the owner wish to sell the property; Land Act, 1998, section 34-36. In South Africa, the Land Reform (Labour Tenants) Act, 1996 and the Extension of Security of Tenure Act, of 1997 provide directly for tenant security. 
including in several states, the right to hold urban property in common [South Africa, Uganda, Tanzania, Namibia].

TABLE 1 TENURE REFORM IN EASTERN AND SOUTHERN AFRICA

\begin{tabular}{|c|c|c|}
\hline COUNTRY & $\begin{array}{l}\text { BASIC NEW TENURE LAWS } \\
\text { And National Land Policies }\end{array}$ & STATUS OF TENURE REFORM 2000 \\
\hline UGANDA & $\begin{array}{l}\text { The Land Act, No } 161998 \\
\text { No National Land Policy } \\
\text { Core 'policy' in Ch. } 15 \text { of } 1995 \text { Constitution }\end{array}$ & $\begin{array}{l}\text { Began 1988. In IMPLEMENTATION. } \\
\text { Under (slow) implementation. } 34 \text { amendments drafted } \\
\text { [August 1999] to modify unworkable plan for } \\
\text { administration, speed dispute resolution, but still not } \\
\text { enacted. }\end{array}$ \\
\hline TANZANIA & $\begin{array}{l}\text { The Land Act No } 41999 \\
\text { The Village Land Act No } 51999 \\
\text { National Land Policy, } 1995\end{array}$ & $\begin{array}{l}\text { Began 1989. Near to IMPLEMENTATION. } \\
\text { Commencement date not yet set; presumed to be after } \\
\text { election, 2000. Drafting of Regulations under the Acts, } \\
\text { national dissemination programme and pilot } \\
\text { implementation planned for } 2000 .\end{array}$ \\
\hline KENYA & $\begin{array}{l}\text { No new tenure laws since 1960s following } \\
\text { first tenure reform of 1950-60s, and two } \\
\text { important amendments never enacted [1994, } \\
\text { 1999]. No single basic land act; } 32 \text { land laws, } \\
12 \text { of which central, with overlap and some } \\
\text { contradiction. }\end{array}$ & $\begin{array}{l}\text { Began 1999. PLANNING UNDERWAY. } \\
\text { Need for harmonisation accepted officially since } 1986 \text { bu } \\
\text { no action until gazettement in November } 1999 \text { of } \\
\text { Commission of Inquiry into the Land Law System in } \\
\text { Kenya. Began work in January 2000. Required to produce } \\
\text { new National Land Policy, but no time frame set. Sharp } \\
\text { criticism of composition of Commission; policy likely to } \\
\text { be hotly debated. }\end{array}$ \\
\hline RWANDA & 1997 Directive on Imidigudu [Villagisation]. & $\begin{array}{l}\text { Began 1997. PLANNING UNDERWAY. } \\
\text { Commitment under terms of Economic and Structural } \\
\text { Adjustment Facility Agreement to produce new NLP and } \\
\text { enact a new basic land law by end 2001. First drafts } \\
\text { allegedly prepared in mid } 1998 \text { but not available to } \\
\text { public. Genuine conundrums as to way forward and fear } \\
\text { of prompting new tribal war. }\end{array}$ \\
\hline ERITREA & Land Proclamation No. 58 of 1994 & $\begin{array}{l}\text { Began 1992. IN IMPLEMENTATION } \\
\text { Mainly education campaigns [1994], research and pilot } \\
\text { areas [four in 1996] and additional legislation but } \\
\text { withdrawn. }\end{array}$ \\
\hline ETHIOPIA & $\begin{array}{l}\text { Land Proclamation, } 1975 \\
\text { Proclamation No. } 89 \text { of } 1997 \text { on Land Re- } \\
\text { distribution. }\end{array}$ & $\begin{array}{l}\text { Began 1975. IN IMPLEMENTATION } \\
\text { Further new law promised in new Constitution } \text { (1992) but } \\
\text { not yet materialised. }\end{array}$ \\
\hline MALAWI & Land Use and Management Bill, 1998 & $\begin{array}{l}\text { Began 1996. PLANNING UNDERWAY. } \\
\text { Commission Report will set terms for new Land Policy. } \\
\text { Bill aims to vest title in customary land in chiefs rather } \\
\text { than President, and to vest public land in Minister, not } \\
\text { President. Not clear that political will for change exists. }\end{array}$ \\
\hline ZAMBIA & $\begin{array}{l}\text { Lands Act No. } 29 \text { of } 1995 \\
\text { DRAFT National Land Policy, } 1998\end{array}$ & $\begin{array}{l}\text { Began 1993. IN IMPLEMENTATION. } \\
\text { New NLP, } 1998 \text { drafted to lead to further tenure reform } \\
\text { and possible reversion of } 1995 \text { provisions. }\end{array}$ \\
\hline
\end{tabular}


Table 1 continued.........

\begin{tabular}{|c|c|c|}
\hline ZIMBABWE & $\begin{array}{l}\text { Land Acquisition Act, } 1992 \text { revised } 1996 \\
\text { Communal Land Act, } 1982 \\
\text { Rural Land Act, Cap. 20:18 } \\
\text { Regional Town and Country Planning Act, } \\
1976 \\
\text { Agricultural Land Settlement Act, Cap. 20: } \\
\text { DRAFT National Land Policy, 1999 }\end{array}$ & $\begin{array}{l}\text { Began 1980. IN IMPLEMENTATION. } \\
\text { Land Reform began at Independence, 1980, centred upon } \\
\text { redistribution of large-scale farms to poor and then skilled } \\
\text { farmers. Acquisition Act, } 1992 \text { used to acquire farms. } \\
\text { Phase II of Reform began } 1998 \text { for further redistribution. } \\
\text { New NLP drafted (1998), subject to consultation, not } \\
\text { clear that political will exists for its adoption. Deals } \\
\text { significantly with tenure issues of the majority. }\end{array}$ \\
\hline $\begin{array}{l}\text { MOZAM } \\
\text { BIQUE }\end{array}$ & $\begin{array}{l}\text { Land Law No. } 19 \text { of } 1997 \\
\text { Regulations, } 1998 \\
\text { Regulations, } 1999 \\
\text { National Land Policy, } 1996\end{array}$ & $\begin{array}{l}\text { Began 1992. IN IMPLEMENTATION } \\
\text { Under implementation, with educative programme as to } \\
\text { rights well underway 'Land Campaign'. }\end{array}$ \\
\hline BOTSWANA & $\begin{array}{l}\text { Amendment to (1968) Tribal Land Act, } 1993 \\
\text { White Paper, 1982. } \\
\text { Agricultural Policy, } 1991\end{array}$ & $\begin{array}{l}\text { Began 1982. COMPLETE. } \\
\text { Amendment increased central powers, provided more } \\
\text { opportunities for converting customary rights to leasehold } \\
\text { forms and weakened construct of land as only accessible } \\
\text { to tribesmen of the area. Agricultural Policy permits } \\
\text { enclosure of rural commons. Proposed new Rural } \\
\text { Development Policy may prompt more change. }\end{array}$ \\
\hline $\begin{array}{l}\text { SOUTH } \\
\text { AFRICA }\end{array}$ & $\begin{array}{l}\text { Redistribution: } \\
\text { Provision of Land and Assistance Act, } 1993 \\
\text { Development Facilitation Act, } 1995 \\
\text { Restitution: } \\
\text { Restitution of Land Rights Act,1994 } \\
\text { Tenure Reform: } \\
\text { Upgrading of Land Tenure Rights Act, } 1991 \\
\text { Interim Protection of Informal Land Rights } \\
\text { Act, } 1996 \\
\text { Communal Property Associations Act, } 1996 \\
\text { Land Reform (Labour Tenants) Act, } 1996 \\
\text { Extension of Security of Tenure Act, } 1997 . \\
\text { Transformation of Certain Rural Areas Act, } \\
\text { 1998 } \\
\text { Land Rights Bill. } \\
\text { National Land Policy, } 1997\end{array}$ & $\begin{array}{l}\text { Began 1993. IN IMPLEMENTATION } \\
\text { Land reform well underway manifest in new laws and } \\
\text { changes on the ground through pilot programmes. } \\
\text { Programme in three thrusts; restitution of lands lost } \\
\text { through racially-discriminatory laws and policies; } \\
\text { redistribution to increase land access of poor and } \\
\text { landless, and tenure reform to improve legal provision for } \\
\text { rights in land for majority. Land Rights Bill to finalise the } \\
\text { last is 'on hold' pending decision of Mbeki administration } \\
\text { as to priorities. Issue of Ministerial statement on land } \\
\text { reform policy Feb.2000 unclear, and relates mainly to } \\
\text { settlement grants by the state. }\end{array}$ \\
\hline NAMIBIA & $\begin{array}{l}\text { Agricultural (Commercial) Land Reform Act, } \\
1995 \\
\text { The Communal Land Reform Act, } 2000 \\
\text { National Land Policy, } 1999\end{array}$ & $\begin{array}{l}\text { Began 1990. IN IMPLEMENTATION } \\
\text { Slow development of policy and new law. Critical law for } \\
\text { communal lands drafted at least five years ago, now in } \\
\text { dispute over local consultative input. }\end{array}$ \\
\hline LESOTHO & $\begin{array}{l}\text { Land Act No. } 171979 \\
\text { Deed Registry Act, } 1967 \\
\text { Land (Agricultural Lease) Regulations, } 1992 \\
\text { Town \& Country Planning (Amendment) } \\
\text { Act, Draft Bill } 1997 \\
\text { Native Administration Proclamation, } 1938 \\
\text { (Cap. 54) }\end{array}$ & $\begin{array}{l}\text { Began 1987. NO IMPLEMENTATION } \\
\text { Mainly because of unresolved conflicts between state and } \\
\text { traditional machinery in land matters, recommendations } \\
\text { from } 1987 \text { Land Review Commission, new } \\
\text { recommendations in 1998, 1999, not effected. New } \\
\text { Commission proposed to make NLP, but not yet in place. }\end{array}$ \\
\hline SWAZILAND & $\begin{array}{l}\text { Diverse laws from } 1910 . \\
\text { Farm Dwellers Control Act, } 1982 . \\
\text { Sectional Titles Act, } 1999 \\
\text { DRAFT National Land Policy, } 1999\end{array}$ & $\begin{array}{l}\text { Began 1999, PLANNING UNDERWAY. } \\
1999 \text { Draft National Land Policy, } 1999 \text { proposing new } \\
\text { law. }\end{array}$ \\
\hline
\end{tabular}




\section{Devolving tenure administration}

The point at which acquisition and disposal of land rights are officially endorsed and regulated is also moving closer to the landholder. The processes are through systems, and by the hand of officers being made more accountable 'downwards' to the clients, the landholders, rather than has been conventionally the case, 'upwards' to Government.

The most 'classical ' democratisation has occurred in Uganda where tenure administration is designed to operate entirely independently of the executive and of local government, through entirely new tenure institutions, district land boards, supported through a network of some 4,500 local level land committees ['parishes']. The sheer scale, cost and hesitant official will, is making this plan difficult to implement in practice [Government of Uganda, 1999]. Amendments are planned but with the retained intention to adjudicate titles at the parish level and to have these recorded at the district or sub-district level. ${ }^{18}$

New tenure law in Tanzania by-passes the district level and directly designates the elected government of each village as the Manager of all land within the range of its respective declared 'Village Area'. Adjudication, recordation, registration, entitlement and land dispute resolution will all take place within, and by each village community. In short, there will be some 9,225 discrete tenure administrations, following the detailed guidance of a new village land law. ${ }^{19}$ Whilst tempered with interventionist powers of state, and the exclusion of government lands, this tenure regime represents one of the more radical departures in tenure administration in the region this last fifty years. ${ }^{20}$ The new law is yet to see commencement but given that it will operate through existing village-based institutions, may have a chance to succeed.

Elsewhere in the region, progress towards devolving powers over tenure has been much less. ${ }^{21}$ Absence of well-developed institutions at the grassroots comparable to the village level of governance evolved in Tanzania since 1975 appears to be a major constraint towards devolving tenure authority in Zambia, Namibia, Zimbabwe, South Africa, Zimbabwe, and Mozambique. This difficulties are exacerbated where there is evident social breakdown of 'community' within which property relations are supposedly entrenched [South Africa, Mozambique]. In Mozambique, for example, the absence of working local government outside towns has left provincial administrations with high authority under new land law and communities without useful institutional form or powers, despite the

\footnotetext{
18 The Land (Amendment) Act, 2000, shortly to be presented to the Uganda Parliament.

The Village Land Act, 1999 and still draft Village Land Regulations , 2000.

The Tanzania Land Act, 1999 divides the land area of Tanzania into General Land [Government Land], Reserved and Village Land. The last is by far the majority category, although Reserved Land does embrace an estimated third of the land area [Forest Reserves and National Parks in particular]. General Land is mainly in urban areas and includes state farms and farms leased to commercial enterprises and private persons.

Eritrea's earlier tenure law schedules but does not elaborate comparable community-based tenure authority [1994]. After twenty years of confining customary rights to Presidential dictate, Zimbabwe is considering a proposal to finally rid itself of the demeaning 'communal lands' framework, to recognise customary tenure as a statutorily-defined regime and to adopt a largely community-based regime for its administration [Government of Zimbabwe, 1998].
} 
orientation of the law towards securing their rights and role [Kloeck-Jenson, 1997]. A main task since has been towards devising legal parameters and process through which communities may at least define themselves and their land areas. ${ }^{22}$ Policy-makers in Rwanda, South Africa and Lesotho are all currently working through ways to develop tenure management regimes which will, for all intents and purposes, render more control over property administration and decisionmaking to the grassroots. ${ }^{23}$

Arguably, the coming decade will see a good deal of local level institutional development, driven to a significant extent by the new demands of 'tenure reform', and one which embraces a wider range of governance reform than in matters of property. The signs are that these will reach beyond the traditional platform of local government, the district level, into the village. So far this has been most concretely delivered in the passage of the Traditional Leaders Act, 1998 in Zimbabwe, designed to widen and democratise the basis of local government beyond district level Councils.

\section{Popularising dispute resolution}

Comparable steps towards devolution are occurring in the locus and means through which land dispute may in future be resolved. Again, new paradigms arise mainly from the overload and unaccountability of current regimes but in the resolution, improve local level access to machinery, participation and client-accountability and in addition, notably take account of customary norms and practices.

The trend has been towards establishing formal tribunals independent of the judiciary, operating at the local level, and in some cases operated by community members [Mozambique, Tanzania, Eritrea]. In most cases these are supplemented by the ordinary courts, to hear certain classes of dispute and to be a source of appeal. This is not the case in Uganda where the proposed tribunal regime is more comprehensive, but also a good deal more expensive to put in place [Government of Uganda, op cit.].

\section{Contrary trends}

Thus, from the above, it may be seen that a real shift in the balance of interests and powers in property matters from centre to periphery, from state to people, is underway, albeit a shift which is hesitant, uneven and still incomplete. Moreover, as is so often the case in such transitions, the overall trend is being countered by opposing forces, resulting in a degree of polarisation of authority at both centre and periphery.

\section{Root powers of state}

No where is this clearer than in the reaffirmation, rather than release, of root powers of state over property, through which governments assure themselves the 'final say'. Thus, amidst all the democratisation (such as it is), all but one nation (Uganda) has firmly entrenched the notion of root title, a notion which awards the state ownership

22 This is a main subject of the 1999 Technical Annex to the Regulations of the Reform Land Act (1997), devised and approved in July 1998.

23 Seen for example in the search for appropriate 'right 'rights holder structures' in the evolving Land Rights Bill of South Africa [Draft June 1999]. 
of the soil and landholders ownership of only interests or rights in land [Alden Wily with Mbaya op cit.]. From this proceeds power to designate, regulate, intervene and appropriate land at will - a facility fulsomely used throughout the sub-continent, and arguably 'abused' in such tenure constructions as 'trust' and 'communal lands', and in acts which re-make trusteeship as outright, rent-seeking landlordism [ibid.].

Sometimes the declaration or reaffirmation that all land is owned by the President/state has been direct and clear as in the tenure legislation of Eritrea, Ethiopia, Tanzania, Mozambique, Zambia and Lesotho (and anticipated in upcoming legislation in Rwanda and Malawi). Sometimes it is not made a founding principle but is nonetheless as evidently operative in the positions of the law, and in the handling of 'communal lands' in particular [Zimbabwe, South Africa, Namibia, Malawi] or in the manner in which states deal with property once it has entered the class of Government or State Land. Nor, on past performance, does the routine avowal that these powers exist in a context of trusteeship significantly lessen the powers secured or the manner of their exercise [Alden Wily with Mbaya, op cit.].

\section{Appropriation of property}

Such new constraint as there is, may be seen mainly in improvement of rates of compensation, and in some new tenure laws, in the accountability of information to those whose land is to be taken [Tanzania, South Africa]. Constitutional declamation aside, not a single new tenure law has significantly narrowed the grounds upon which property may be appropriated, and the notion of 'public purpose' remains as much a Pandora's box of opportunity as in the past and just as easily able to slip into the realm of what is more properly private purposes. And whilst the process of appropriation has seen improvement in several laws, it is only in the new tenure laws of Tanzania [1999] that this has been constructed to proscribe unjustified appropriation of unregistered lands. Fortunately, this lead is spilling over into sectoral law, such as in the constraint now being placed upon the creation of Forest Reserves in the draft Forest Bill of Tanzania, an important development given that reserve creation remains of the main reasons why national governments continue to appropriate local communal property [Alden Wily, 2000b].

\section{Conditions and limitations}

There are other ways through which the state routinely exerts control over the status and transfer of property. 'Conditionality' to agriculture rights - a long-standing feature of African tenure regulation - is, elsewhere just as evident in new tenure laws as in old, despite a good deal of evidence that adherence is erratic at best [Alden Wily with Mbaya, op cit.]. The legal requirement to physically occupy and use such lands is pervasive [Tanzania, Zambia, Ethiopia, Eritrea, Namibia, Botswana, Lesotho, Mozambique]. Ceilings upon agricultural landholding are also being imposed, designed to further limit land hoarding and absentee landlordism [Tanzania, Eritrea, Ethiopia, Botswana, Lesotho and Namibia].

These reinforce the apparent intention to constrain the market in land, particularly as affecting the unregistered, customary sector [Tanzania, Mozambique, Eritrea, Ethiopia, Rwanda, Zambia, Zimbabwe, Lesotho]. This is despite early intentions of most of these same states to promote a free market in property. Limitation is as marked in respect of non-citizens, who are mainly permitted access only through 
leaseholds [Uganda, Ethiopia, Eritrea, Zambia, Zimbabwe, Mozambique, Lesotho] and usually only when such acquisition is approved as for commercial investment purposes evidenced by the introduction of substantial foreign exchange. In Tanzania, non-citizen access to customarily-held property has been made illegal under the terms of new tenure law, but the state itself may 'remove' land from that category and rent it out to foreigners itself. ${ }^{24}$

\section{THE FUNDAMENTAL REFORM: REMAKING CUSTOMARY LAND TENURE}

What these developments, lightly touched upon above, illustrate is that in certain quarters security of tenure over land is indeed improving and with evident greater attention throughout to the rights of the ordinary citizen and towards the protection of that right. It is however, from a single quarter that the most dramatic transformation is being made and one that drives many of the above developments. This is in the manner in which rural customary interests in land are being treated in new national land law in the region. As shown shortly, these in turn directly affect the status of traditional common properties.

\section{Transformation in customary land rights}

The facts are these. Despite a century of purposeful penetration of non-customary tenure ideology and legal provision as briefly outlined earlier, unregistered, customary tenure not only persists but is by far and away the majority form of tenure in the region at the beginning of the new century. None of the strategies adopted to ignore or diminish it have been successful.

Even where early efforts to consider customary rights in national law were made, these tended to refashion those rights into forms acceptable to dominant European norms and are gradually now coming under revision. Thus the muchadmired integration of customary tenure into statute in Botswana in the late sixties [Tribal Land Act, 1968] 'forgot' to incorporate the most critical element of agro-pastoral tenure, commonage, a lacuna which has plagued land relations in that country since ${ }^{25}$ - and a lacuna which is about to visited upon the lands of the black majority in Namibia through the Communal Lands Reform Act, should it remain in place. ${ }^{26}$

Meanwhile, to add affront to the assumptions and designs of officialdom, many of the attributes of traditional tenure regimes have made their way into transfer mechanisms of even 'modern' titled property, engendering a plethora of dispute particularly in matters of inheritance, and for which the current range of enactment provides unsatisfactorily resolution. This has begun to prove

24 Land Act, 1999, section 5. Debate as to how far villagers should be permitted to sell or lease land to non-citizens was an issue of debate in policy-making [1992-1995] and later in the drafting of the new land law [1996-1998].

$25 \quad$ As evidenced in the Tribal Lands Grazing Policy, 1975 and see White, 1998.

This law was not passed by the Namibian Parliament without a good deal of contention and dissent and there is now some doubt that it will be approved by the National Council [Maletsky in The Namibian, $9^{\text {th }}, 11^{\text {th }}, 18^{\text {th }}$ February, 2000 and 16 March, 2000. 
particularly problematic in those states where registration processes are ineffective [Kenya, Uganda, Zambia]. Urban-rural distinctions provide a similar source of conundrum, with town and country planning legislation found wanting in its capacity to determine the tenure of those whose traditionally-held property is now so routinely absorbed into urban sprawl [Tanzania, Zimbabwe, Uganda].

\section{Capitulation}

It is not surprising that decision as to the future of unregistered and customary rights, as well as the future of the mechanisms through which they are handled [customary tenure], has come to represent the single most important 'problem' facing current tenure reform in the region.

Its resolution is also proving the most influential upon decisions in other areas. Indeed, if there were a single point of radicalism in tenure reform occurring in Sub-Saharan Africa today, it is this; that for the first time in one hundred years, states are being forced to recognise African tenure regimes as legal in their own right and equivalent in the eyes of national law to the freehold/leasehold culture.

All sorts of implications proceed from this, few more welcome to national governments than their resigned recognition in the first instance, that unrecorded traditional land rights will have to be given the full weight of national law after all.

Response is diverse and uneven in intent. But action is being taken on many fronts [TABLE 2]. In Eritrea, majority customary rights have been reconstructed into inheritable lifetime usufructs guaranteed state protection (1994). In Zambia, the accelerated thrust towards the conversion of customary rights into leaseholds of 1995 land law is now under reconsideration in draft national land policy (1999). In South Africa, whilst in the first years of post-apartheid governance, thinking was strongly towards an individualisation and entitlement programme into freeholds, this has been redirected through two pressures; first, from claims by traditional leaders to hold the land themselves as owner/trustees ['tribal land'], and second, from pressure to provide for the fact that significant parts of these areas are held in common, not individually. The drafting of the Land Rights Bill began with these concerns in mind, concerns which may yet see its abandonment through the contradictions tribal and local community ownership of lands pose. ${ }^{27}$

The Preliminary Report of the Malawi Land Commission [1998] suggests a similar movement towards the democratisation of root title of customary land, in this case to village chiefs/headmen, and with limitation of state powers over these properties. This is but a short step towards coming up with the idea of offering Customary Titles such as in Tanzania and Uganda (and proposed in Zimbabwe). Some doubt has been expressed as to the level of political will for some depths of tenure reform [Palmer, op cit.].

The hopeful developments in Zimbabwe towards securing informal and customary rights have been noted earlier; the draft policy discussion paper proposes the establishment of a multiple tenure system such as in Uganda in which the different

27 See Ntsebeza, op cit., Adams, 1999, DLA 2000, Palmer, forthcoming. 
regimes are 'equal in status, and interests under each of them, enjoying adequate security of tenure under law', a badly needed development in a modern country where customary rights have continued to be degraded following independence [Government of Zimbabwe, 1998/99]. The plan proposes devolution of root title to village communities and comparable devolution of tenure administration to the village level, at which level adjudication and entitlement would take place. In the interim there would be assurance of security of informal [unregistered] customary rights [ibid.].

However, the clearest lead of all is being given in the new tenure laws of Uganda, Tanzania and Mozambique, already in place. In different ways, these reforms take the obvious but historically extraordinary step of simply recognising customarilyobtained land as fully legally tenured 'as is', in whichever form and with whatever characteristics they currently possess. In addition they may be made registrable entitlements if so desired. New land laws in those states imply or state equivalency in the status and security of unregistered and registered rights in land. The Tanzania Land Act, 1999, is the one law to make this principle explicit [s. 4(6)] and to structure a good deal of the sister Village Land Act, 1999, around making this real. In Uganda, equivalency is offered in the recognition by the new Constitution of customary tenure as one of four legal regimes, and provision in the new land law for these to be registered - no mean victory for customary owners who have both been tenants of state for years and whose regime of landholding was marked for abolition in the early stages of the tenure reform process [Alden Wily, 1997].

\section{Changing notions of tenure}

These developments undermine the very principles upon which property relations have been legally constructed over the last century.

Even the centre-piece of twentieth century African land tenure transformation, entitlement, is of necessity being 're-made'. Previously, recordation, registration, and the issue of evidential documentation [titles] were inseparable from the individualisation of the ownership of that property and the elimination of any layers of other rights which might pertain. Now, the link has been broken. Whilst certification remains an impregnate objective towards land security throughout the region, it is no longer necessarily for the purpose of individualisation. Nor with new legal respect being afforded un-certified rights - a logical consequence of recognising customary tenure - will the espoused sanctity of title deeds have the same resonance in the law or in the courts. Routinely-provided constitutional commitments towards the sanctity of 'private property' take on new meaning.

The long-assumed essentiality of individualisation of property for economic security and growth has also come into doubt. ${ }^{28}$ To summarise, reiterated 'facts' are that title

\footnotetext{
28 . The arguments have been amply covered elsewhere and need only cursory note. Much of the 'evidence' is in fact secondary, authors citing a limited number of empirical studies, such as MigotAdholla, Place \& Oluoch-Kosura 1994, Carter, Wiebe \& Blarel, 1994, Roth, Cochrane \& KisambaMugerwa, 1994, and Roth, Unruh \& Barrows, 1994. The general case is argued in Shipton, 1989. Deininger \& Binswanger, 1999 elaborate resulting changing World Bank position in this area. Other prominently-cited papers not available to this author include Barrows, R. and M. 'Land Tenure and Investment in African Agriculture: Theory and Evidence' in Journal of Modern African Studies, No. 28,
} 
has not generated available credit to smallholders, titled smallholdings are not generally accepted as collateral, and that inputs an improvements to farms do not correlate with the type of title [registered or customary]. The promised reduction in land disputes through titling has also not materialised; on the contrary dispute over ownership has multiplied and become a good deal more complicated and expensive to resolve. The cost-efficiency of the titling process has also been thoroughly disputed. ${ }^{29}$ The final nail in the coffin of individualisation according to (most) critics is that the holding of land by customary means does not in itself inhibit market transactions.

What these arguments correctly do is to put the titling process under review. Two main trends are observable; firstly, steps to simplify and decentralise the process of recording and certifying rights in land [Certificates of Title] as has been indicated above, and secondly as widespread steps to expand the meaning of 'private' beyond the individual, to allow for spousal, family, clan and other group forms of ownership.

The very notion of what constitutes 'private property' has thus begun to expand its conventional boundaries to embrace a simple - and traditional - idea more than a single person may own private property. The certification process itself has to change. It may be verbal and verbally endorsed [Mozambique]. The community itself may conduct the adjudication, recordation and entitlement process [Tanzania]. The incidents of the title may be in accordance with custom and the regimes through which these rights are created and sustained, are empowered. By being forced to acknowledge that customary landholding may exist in perpetuity, customary rights in Tanzania and Mozambique have actually been rendered 'superior' to other forms of tenure available [rights with limited term] a pleasing reversal or tenurial fortune for the rural majority.

\section{NEW LIFE FOR COMMON PROPERTY}

New political and legal perspective upon 'commonage' is integral to this development. In many respects this represents the 'cutting edge' of the transformation in tenure relations occurring. It is certainly the sharpest in its implications.

In Uganda, new law for the first time includes direct recognition of land ownership beyond the individual, as extended households, groups, clans or otherwise, and provides for its entitlement as such (Land Act, 1998). It also provides for Communal Land Associations to be formed to own and manage (larger) tracts of land [TABLE 2].

Similarly, new law in Tanzania provides for the first time for common property to exist in national law and to be registrable. There is nothing token about the manner

1990, and Platteau, J-P. 'Reforming Land Rights in Sub-Saharan Africa: Issues of Efficiency and Equity' UNRISD Discussion Paper No. 60, 1995 [Geneva].

${ }_{29} \quad$ See Platteau, 1992, Chapter Three. 
in which this is expressed in the law. Repeated reference is made to the landholding and registration capacity of not just individual persons but 'a family unit, a group of persons recognised as such under customary law, or who have formed themselves together as an association, a primary co-operative society or as any other body recognised by any law' [Village Land Act, 1999 s. 22 (1)]. ${ }^{30}$ As with all customary rights in lands, these communal rights will be 'in every respect of equal status and effect' to the leasehold-type rights issues directly by Government ('Granted Right of Occupancy') [s. $18(1)$ ].

The new law does more than recognise common property as a legal and registrable form of ownership - it encourages this. The Village Land Act requires the members of each and every village community to 'set aside' all those parts of their area which they agree should be held as common land by the community as a whole, through processes set out in the act (s. 13). This has to be undertaken prior to any exercise seeking to register and title individual or household landholding. Existing common lands shall be deemed as commonly held and to be registered in the Village Register [s. 13(6) \& (7)]. This will place restraint upon the further subdivision and individualisation of lands during adjudication and registration.

The implication of this tenure development for rural communities (all of which are located in so-called Village Lands) to secure woodland, swamps, range as their own statutory commonhold is considerable. However 'a group of two or more persons' may also hold such title in government land [General Land] and Reserved Land, [Land Act, s. 19]. ${ }^{31}$ This provides a legal opportunity for groups of persons to secure title to Reserved Land - a fact of direct and positive implication to community-based forest tenure and management [see later].

Currently, there is no provision in Zimbabwe for ready statutory possession of common property such as is now possible in Tanzania. However, the draft National Land Policy borrows extensively from Tanzanian developments and inter alia, recommends provision for customary land to be held by groups and for village councils to hold local common property and to manage it in the interests of the village membership. ${ }^{32}$ As observed earlier, this policy is still under discussion, and is, without doubt, for the moment in the shadow of the more controversial debate as to the restitution of white-owned properties. ${ }^{33}$

The new land law in Mozambique provides in principle for communities or groups of persons to hold land in a statutorily-recognised manner [Article 7] and to 'observe the principles of co-title'. The title to a local community 'shall be issued in the name chosen by the local community' [Article 10 (4)]. This helpfully puts paid to the need for a community to construct itself first into a legally-recognised body. 'Community'

\footnotetext{
The need for the group to either have an existing legal basis or to be recognised as a customary formation, appears restrictive until it is noted that customary group formation potentially covers all options for group formation. Still, occasions might arise where an absence of this proscribes the holding of land by, for example, a women's group. Although in this case as statutorily rather than customarily onstituted groups such as through a Trust, Company or Co-operative [s.19 (1) (2)].

32 Government of Zimbabwe, op cit. pages 128-130.

An up-to-date account of the debate and events surrounding it provided by van den Brink,
} 2000. 
itself is defined in the law in the most generous of terms as a group of families and individuals living within a geographical area at the territorial level of a locality or subdivision thereof and which seeks to safeguard its common interests through the protection of areas for habitation or agriculture including both fallow and cultivated areas, forests, areas of cultural importance, pasture land, water sources and areas for expansion [Article 1].

As with the new Tanzanian law, the absence of paper title will explicitly not prejudice the legality of such holdings [Article 10 (2)]. The Regulations under the act reiterate in no uncertain terms that verbal testimony will have the same value in terms of the law as a title deed [July, 1998, Article 14 (2)]. This is just as well for the procedures and cost of securing a title deed is made the same for all classes of tenure and is beyond the means of rural communities. ${ }^{34}$ Definition of community land is itself proving problematic in Mozambican law, with the final technical annex to the law falling back on a less than satisfactory definition of community area as that of the political-administrative unit of locality [localidade].

In South Africa, the Communal Property Associations Act, 1996 was enacted to enable groups of people to acquire and manage property as groups. The procedure has shown itself as somewhat bureaucratic, and has not been widely adopted. ${ }^{35}$ Related problems have been reported in the nature of groups applying for land, identified often as less communities with traditional interests than 'sets of individuals who have come together with little if any previous mutual involvement for the sole purpose of getting sufficient critical mass to purchase a farm' [DLA, 1999]. Where traditional tribal authority is well entrenched, movement into operations of community-based rather than chief-led co-operation has also proved difficult. ${ }^{36}$

The need to provide for the holding of property in common has nonetheless become more, not less, clear to policy and law makers in recent years. The Draft Land Rights Bill seeks to make it as simple as possible by providing for common rights to be deemed to be 'protected rights' in equal degree to those held individually. Common rights may accrue through membership to either a legal entity or community [s. 9 (2)]. The Bill also provides for a community (as well as individuals, legal entities, communal property associations, etc.) to seek to have their land transferred out of state land into private property as a 'commonhold title' [s. 37]. A commonhold title is defined as communal ownership and use of land, in perpetuity, and governed by the 'shared rules of the member of the community' [s. 45]. It is equivalent to an absolute right. Should the Bill ever enter law, then it is highly likely that this will be the most popular route to secure group tenure, and the constructs of community trusts and Communal Property Associations and Trusts will drop away.

By no means all states have adopted commonhold entitlement into their new laws or necessarily plan to do so. In Botswana, for example, revisions made to the Tribal

34 Estimated as around US\$10,000 to survey, demarcate and title an area of for example, 12,000 ha, under the current regulations of the Surveyor-General's Department; Mushove, 2000.

Grundy, 2000. A review of the land reform support programme showed that the CPA route is not favoured, with a preference for registering as a group is as Trusts, a more established, user-friendly and comprehensible format [DLA, 1999]. Securing formal rights not through any new legal form but under the umbrella of local authorities, also appears to be popular - and effective [ibid.].

DLA, 1999. 
Land Act in 1993 specifically did not include development towards statutory commonhold in tribal lands, instead retaining the expansive commonage as unregistered and in effect open access land, made available for subdivision and enclosure through common law leaseholds. Moreover, the 1993 Amendment opened up access to these lands beyond tribal members of the local tribal land to all citizens. $^{37}$

The 1998 National Land Policy of Namibia suggests the adoption of a communal associations route, with probably similar results as experienced in South Africa. Groups of persons may hold land jointly but only as 'legally constituted family trusts' or 'legally constituted bodies and institutions' [s. 1.11]. This means groups of persons first have to register their existence to the satisfaction of one or other statute, and then proceed to make claim. This intention is oriented towards urban lands [section 2.5]. Support for common property rights in rural areas is weak in policy. Section 3.3 dealing with rural land actually limits this opportunity, saying that tenure rights will be exclusive individual rights, lamely offering that 'However, the sharing of land and natural resources to mutual benefit between neighbours will be encouraged, particularly in times of drought and other stress'. The issue of customary grants [s. 3.4] and their registration [s. 3.5] do not provide for communal or private group tenure. Section 3.9, dealing with grazing makes no provision for rights in communal grazing to be registered or titled.

All the above have now been put into the Communal Land Reform Act. That law states that the President (as owner of the land) has the right to withdraw any area of communal land into State Land, emphasised in reference to commonage for grazing. ${ }^{38}$ In short, the intention is towards the abolition of commonage in favour of its enclosure and entitlement in individually-held leaseholds.

The Zambia Draft Land Policy, 1999, is similarly oriented towards prompting and providing for the individualisation of property. As currently drafted, the policy suggests that while recognition of customary rights will be enhanced through new legislation, the direction may well be towards further facilitating its conversion into individualised leaseholds, begun with the 1995 law. Current land law in Lesotho, Swaziland, Malawi, Rwanda and Kenya make no provision for statutory common titles.

\footnotetext{
Section 10 of Tribal Land (Amendment) Act, No. 14 of 1993, amending section 15 of Tribal Land Act, Cap. 32:02.

Sections 16 (1) (c)], 29 (1) (c).
} 
TABLE 2 OVERVIEW OF PROVISION FOR CUSTOMARY TENURE, ENTITLEMENT, AND COMMUNAL PROPERTY IN NATIONAL LAND LAWS IN EAST AND SOUTHERN AFRICA

\begin{tabular}{|c|c|c|c|}
\hline " COUNTRY & $\begin{array}{l}\text { NATIONAL LAND LAW } \\
\text { PROVIDES FOR } \\
\text { CUSTOMARY LAND LAW }\end{array}$ & $\begin{array}{l}\text { DIRECT TITLE FOR } \\
\text { CUSTOMARY RIGHTS } \\
\text { AVAILABLE }\end{array}$ & $\begin{array}{l}\text { TENURE LAW RECOGNISES COMMON } \\
\text { PROPERTY AS A LEGAL AND PRIVATE } \\
\text { RIGHT IN LAND }\end{array}$ \\
\hline UGANDA & $\begin{array}{l}\text { YES } \\
\text { Fully legal as one of four } \\
\text { regimes in plural system } \\
\text { Constitution [Article } 237 \text { (3) } \\
\text { (a)] }\end{array}$ & $\begin{array}{l}\text { YES } \\
\text { Directly through Certificate of } \\
\text { Customary Ownership [s. 8, } \\
\text { Land Act, 1998]. } \\
\text { Also provides for conversion to } \\
\text { freehold if the owner wishes and } \\
\text { if customary regime allows [s.12- } \\
\text { 14]. }\end{array}$ & $\begin{array}{l}\text { YES } \\
\text { Land Act, } 1998 \text { provides for its registration } \\
\text { and entitlement as communal property [TLA } \\
1998 \mathrm{s.4}(1) \text { (f)]. Section } 5 \text { provides for 'any } \\
\text { person, family or community holding land } \\
\text { under customary tenure... may acquire a } \\
\text { certificate of customary ownership'. } \\
\text { Act also provides for formation of a Communal } \\
\text { Land Association [s.16] 'by any group of } \\
\text { persons ... for any purpose connected with } \\
\text { communal ownership and management of } \\
\text { land, whether under customary law or } \\
\text { otherwise'. An association must follow act in } \\
\text { setting aside land for common use through } \\
\text { formulation of a 'common land management } \\
\text { scheme' [TLA } 1998 \mathrm{s.24} \& 25,26,27] .\end{array}$ \\
\hline TANZANIA & $\begin{array}{l}\text { YES } \\
\text { Fully recognised as one of } \\
\text { two regimes by Land Act, } \\
1999 \text {, Customary and } \\
\text { Granted Rights [s. } 4 \text { (1)]. 'To } \\
\text { ensure that existing rights in } \\
\text { and recognised long- } \\
\text { standing occupation or use } \\
\text { of land are clarified and } \\
\text { secured by the law' made a } \\
\text { main objective and principle } \\
\text { of the new law [s. 3(1) (b)]. . }\end{array}$ & $\begin{array}{l}\text { YES } \\
\text { Customary Right of Occupancy. } \\
\text { Village Land Act, } 1999 \text { is mainly } \\
\text { for adjudicating, recording, } \\
\text { registering and issuing titles for } \\
\text { customary rights. No capacity to } \\
\text { convert directly to Granted } \\
\text { Rights. }\end{array}$ & $\begin{array}{l}\text { YES } \\
\text { Commonage: } \\
\text { Village Land Act, } 1999 \text { requires each village to } \\
\text { identify and register all communal land with } \\
\text { approval of the membership of the village } \\
\text { [Village Assembly] [s. 13]. A Register of } \\
\text { Communal Land to be maintained by each } \\
\text { Village Land Council [s.13 (6)] and cannot be } \\
\text { allocated for private ownership by individuals, } \\
\text { families, groups [s.12 (1) (a)]. } \\
\text { Private group property: either through Granted } \\
\text { Rights in General and Reserved Land [Land } \\
\text { Act, s.19] or through Customary Right in } \\
\text { Village Lands [most of country land area] } \\
\text { [Village Land Act, s. 22]. Provision also made } \\
\text { for holding land by joint occupancy or } \\
\text { occupancy in common [Land Act, Part XII]. }\end{array}$ \\
\hline KENYA & $\begin{array}{l}\text { PERMISSIVE ONLY } \\
\text { Assumed that customary } \\
\text { tenure will disappear as } \\
\text { Trust lands are converted to } \\
\text { freehold tenure. In interim, } \\
\text { customary tenure may } \\
\text { continue [s. } 115 \\
\text { Constitution]. }\end{array}$ & NO & $\begin{array}{l}\text { NO } \\
\text { Other than through corporate type holdings. } \\
\text { Registrable interests to persons other than an } \\
\text { individual is provided through the Land (Group } \\
\text { Representatives) Act, } 1968 \text { and associated } \\
\text { amendment in the Land Adjudication Act and } \\
\text { Registration of Land Act, Cap } 300 \text {, but this law } \\
\text { de-activated due to administrative directive in } \\
1979 \text { that group ranches should subdivide into } \\
\text { individual plots and no new group ranches } \\
\text { being created. }\end{array}$ \\
\hline RWANDA & $\begin{array}{l}\text { SUSPENDED } \\
\text { Recognised and regulated } \\
\text { through laws of 1960, 1961, } \\
\text { 1975, 1976, but since 1994 } \\
\text { genocide, land rights in } \\
\text { effect suspended, pending } \\
\text { new settlement and tenure } \\
\text { plans. }\end{array}$ & $\begin{array}{l}\text { NO } \\
\text { By definition in laws customary } \\
\text { rights are unregistered [ } 90 \% \text { of } \\
\text { land area]. }\end{array}$ & $\begin{array}{l}\text { NO } \\
\text { Virtually no common land remains other than } \\
\text { minor grazing areas in one province [Umutara] } \\
\text { now also becoming scarce. }\end{array}$ \\
\hline
\end{tabular}




\begin{tabular}{|c|c|c|c|}
\hline ERITREA & $\begin{array}{l}\text { PERMISSIVE ONLY } \\
\text { Abolished by } 1994 \text { Land } \\
\text { Proclamation but permitted } \\
\text { to operate until } \\
\text { implementation of } \\
\text { proclamation complete as } \\
\text { long as does not contradict } \\
\text { principles of Proclamation }\end{array}$ & $\begin{array}{l}\text { NO } \\
\text { Only in converted form. Lifetime } \\
\text { Usufruct intended to be } \\
\text { registered and titled eventually } \\
\text { and has incidents of most } \\
\text { customary tenure regimes. }\end{array}$ & $\begin{array}{l}\text { YES } \\
\text { Collective ownership of interests in land by } \\
\text { community, subject to root title of state, } \\
\text { permits common property ownership to } \\
\text { continue and may evolve into registrable form } \\
\text { once registration of rights begins. }\end{array}$ \\
\hline ETHIOPIA & NO & $\mathrm{NO}$ & $\begin{array}{l}\text { YES } \\
\text { Collective ownership of the rights to hold and } \\
\text { manage land being implemented under } \\
\text { Peasant Associations. }\end{array}$ \\
\hline SUDAN & NO & $\mathrm{NO}$ & $\begin{array}{l}\text { NO } \\
\text { Unregistered Land Act of } 1971 \text { confirms state } \\
\text { ownership of pasture and wadis not } \\
\text { permanently cultivated [i.e. grazing land] and } \\
\text { makes it open to all citizens [open access]. } \\
\text { Has undermined group tenure and } \\
\text { management regimes. }\end{array}$ \\
\hline "DJIBOUTI & $\begin{array}{l}\text { YES } \\
\text { Recognised as the } \\
\text { foundation of property } \\
\text { relations in rural areas. New } \\
\text { statutory laws [1991] allow } \\
\text { state to appropriate certain } \\
\text { lands and to regulate others. } \\
\text { Urban tenure is statutory. }\end{array}$ & "NO & $\begin{array}{l}\mathrm{NO} \\
\text { Registration in respect of water rights only. }\end{array}$ \\
\hline MALAWI & $\begin{array}{l}\text { PERMISSIVE ONLY } \\
1965 \text { Land Act gave Minister } \\
\text { powers to grant leases out } \\
\text { of customary land with no } \\
\text { consultation [s. } 25-26] .\end{array}$ & $\begin{array}{l}\text { NO } \\
\text { The Customary Land } \\
\text { (Development) Act allows for the } \\
\text { conversion of customary land to } \\
\text { freehold [30,000 leases granted } \\
\text { by Minister in 1994]. }\end{array}$ & $\mathrm{NO}$ \\
\hline$\overline{Z \text { ZAMBIA }}$ & $\begin{array}{l}\text { YES } \\
\text { Recognised as one of two } \\
\text { regimes; customary and } \\
\text { leaseholds [Land Act, 1995, } \\
\text { s. 7], but procedures } \\
\text { centralised into hands of } \\
\text { government. }\end{array}$ & $\begin{array}{l}\text { AMBIVALENT } \\
\text { Only through a converted form - } \\
\text { Customary Leasehold Title } \\
\text { [Lands Act, 1995;s.8]. }\end{array}$ & $\begin{array}{l}\text { NO } \\
\text { Customary holdings [not registered] to be } \\
\text { recognised and continue so group holdings } \\
\text { will continue to exist [s.7] but without } \\
\text { registrable entitlement. }\end{array}$ \\
\hline ZIMBABWE & $\begin{array}{l}\text { PERMISSIVE ONLY } \\
\text { Communal Land Act, 1982, } \\
\text { recognises customary } \\
\text { tenure but vests ownership } \\
\text { in President and only } \\
\text { occupation and use rights } \\
\text { may be granted. }\end{array}$ & $\begin{array}{l}\text { NO } \\
\text { Permits to Occupy only, and for } \\
\text { business purposes [Communal } \\
\text { Land Act, } s .9(1) \text { ]. Draft Policy } \\
1998 / 1999 \text { proposes issue of } \\
\text { Customary Certificates to } \\
\text { individuals, groups, village } \\
\text { councils }\end{array}$ & $\begin{array}{l}\text { NO } \\
\text { But Draft National Land Policy 1998/99 } \\
\text { proposes that communities will be able to } \\
\text { register joint interest in land. }\end{array}$ \\
\hline $\begin{array}{l}\text { MOZAM } \\
\text { BIQUE }\end{array}$ & $\begin{array}{l}\text { YES } \\
\text { Major thrust of new Land } \\
\text { Act, 1997, Article } 9 .\end{array}$ & $\begin{array}{l}\text { YES } \\
\text { Through registration of land } \\
\text { under the name of rural } \\
\text { communities, name chosen by } \\
\text { themselves, or individuals, or } \\
\text { other. }\end{array}$ & $\begin{array}{l}\text { YES } \\
\text { Land Law, Article } 7(1) \text { of } 1997 \text { provides for } \\
\text { local communities to hold 'the right of land use } \\
\text { and benefit'. }\end{array}$ \\
\hline
\end{tabular}




\begin{tabular}{|c|c|c|c|}
\hline BOTSWANA & $\begin{array}{l}\text { YES } \\
\text { Tribal Land Act, } 1968 \text { brings } \\
\text { customary regimes and } \\
\text { rights into national law but } \\
\text { modifies by removing root } \\
\text { title and allocation powers } \\
\text { from chiefs to district land } \\
\text { boards and restructures } \\
\text { rights not necessarily in } \\
\text { accordance with custom. }\end{array}$ & $\begin{array}{l}\text { YES } \\
\text { Certificate of Customary Land } \\
\text { Grant, [Tribal Land Act, Part III]. } \\
\text { Now the commonest title in } \\
\text { Botswana although richer } \\
\text { persons with larger holdings tend } \\
\text { to secure common law } \\
\text { leaseholds over same } \\
\text { 'customarily-held' land. }\end{array}$ & $\begin{array}{l}\text { NO } \\
\text { Tribal Land Act, Cap. } 34: 02 \text { provides for } \\
\text { entitlement to individuals, with those spheres } \\
\text { where common lands exist, grazing rights, } \\
\text { largely remain as unregistered common land, } \\
\text { or subject to enclosure and individualisation } \\
\text { as individual common law leaseholds [Tribal } \\
\text { Land Act, Part IV]. }\end{array}$ \\
\hline $\begin{array}{l}\text { SOUTH } \\
\text { AFRICA }\end{array}$ & $\begin{array}{l}\text { YES } \\
\text { Constitution [Article 211] } \\
\text { and Land Policy [1997] } \\
\text { secure customary rights in } \\
\text { principle. Interim Protection } \\
\text { of Informal Land Rights Act, } \\
\text { 1996, provides security } \\
\text { pending Land Rights Bill. } \\
\text { Extension of Security of } \\
\text { Tenure Act, 1997, helps } \\
\text { occupiers on others' land } \\
\text { secure occupancy and even } \\
\text { acquire the land in certain } \\
\text { conditions. Transformation } \\
\text { of Certain Rural Areas Act, } \\
\text { 1998, gives interim local } \\
\text { security to } 23 \text { 'coloured' } \\
\text { areas. }\end{array}$ & $\begin{array}{l}\text { NO } \\
\text { Through 'conversion' into } \\
\text { freeholds, leaseholds, and via } \\
\text { establishing a Communal } \\
\text { Property Association. Draft Land } \\
\text { Rights Bill will, if passed, provide } \\
\text { for registration and titling of rights } \\
\text { as protected rights or through } \\
\text { removing from state land into } \\
\text { private rights of freehold or } \\
\text { commonhold. }\end{array}$ & $\begin{array}{l}\text { YES } \\
\text { Communal Property Associations Act, } 1996 \\
\text { enables groups to collectively acquire, hold } \\
\text { and manage property. Ownership vested in } \\
\text { the members of the group, not the chief, tribal } \\
\text { authority or committee. Draft of Land Rights } \\
\text { Bill [not gazetted] proposed capacity to } \\
\text { register occupancy in common and to secure } \\
\text { ownership through a commonhold title. Not } \\
\text { clear yet if will enter law. }\end{array}$ \\
\hline NAMIBIA & $\begin{array}{l}\text { YES } \\
\text { But with ownership vest in } \\
\text { state [Constitution, } \\
\text { Communal Land Reform } \\
\text { Act, 2000] and with } \\
\text { promotion of conversion of } \\
\text { all but homes \& farms to } \\
\text { leaseholds. }\end{array}$ & $\begin{array}{l}\text { YES } \\
\text { Customary Grants to be issued } \\
\text { under Communal Land Reform } \\
\text { Act, } 2000 \text { for homes and farms } \\
\text { by Regional Land Boards. } \\
\text { Lifetime only. No provision for } \\
\text { grazing or other lands, which will } \\
\text { be by leaseholds. }\end{array}$ & $\begin{array}{l}\text { LIMITED } \\
\text { Only through registered 'family trusts' and } \\
\text { other such legal bodies and these mainly for } \\
\text { urban areas. Issue of rural customary grants } \\
\text { is to be to individuals/ households and in } \\
\text { respect of residential and arable plots only. }\end{array}$ \\
\hline LESOTHO & $\begin{array}{l}\text { AMBIVALENT } \\
\text { The customary Laws of } \\
\text { Lerotholi provide for the } \\
\text { allocation of land by } \\
\text { traditional authorities, } \\
\text { answerable to the King as } \\
\text { per customary modes. } \\
\text { However, the } 1979 \text { Land Act } \\
\text { made void the customary } \\
\text { system of land allocation } \\
\text { and with it, the power of } \\
\text { chiefs. Conflicting } \\
\text { allocations continue with } \\
\text { high level of dispute. }\end{array}$ & $\mathrm{NO}$ & $\begin{array}{l}\mathrm{NO} \\
\text { Grazing land communally owned but not } \\
\text { registrable as such. }\end{array}$ \\
\hline SWAZI. & $\begin{array}{l}\text { YES } \\
\text { Operates within feudal } \\
\text { kingship regime in Swazi } \\
\text { National Lands; these } \\
\text { owned by King, held in trust } \\
\text { for the Swazi Nation. Swazi } \\
\text { Administration Order, 1998, } \\
\text { endorsed chiefly authority } \\
\text { over these lands. }\end{array}$ & $\mathrm{NO}$ & $\begin{array}{l}\mathrm{NO} \\
\text { Grazing land communally owned but not } \\
\text { registrable as such. }\end{array}$ \\
\hline
\end{tabular}


$\begin{array}{ll}\text { TABLE } 3 & \text { PROVISION IN NEW FOREST LAW FOR COMMUNITY-OWNED FOREST }\end{array}$ RESERVES

\begin{tabular}{|c|c|c|c|}
\hline COUNTRY & $\begin{array}{l}\text { STATUS OF NEW FOREST } \\
\text { POLICY \& LAW }\end{array}$ & $\begin{array}{l}\text { CURRENT/PROPOSED } \\
\text { RESERVES [FR] \& } \\
\text { Protected Areas }\end{array}$ & $\begin{array}{l}\text { LEGAL PROVISION FOR } \\
\text { COMMUNITIES TO OWN } \\
\text { FOREST/WOODLAND }\end{array}$ \\
\hline UGANDA & $\begin{array}{l}\text { Forest Act Cap } 246[1964] \\
\text { Draft Forestry Policy, 2000 }\end{array}$ & $\begin{array}{l}\text { Central FR } \\
\text { National Forest Park } \\
\text { Local FR }\end{array}$ & $\begin{array}{l}\text { Likely in new law. Provided for in } \\
\text { Land Act, } 1998 \text { through } \\
\text { recognition customary property }\end{array}$ \\
\hline TAANZANIA & $\begin{array}{l}\text { Forest Ordinance Cap } 389 \text { [1957] } \\
\text { National Forest Policy, 1998 } \\
\text { Draft Bill for the Forest Act, } 2000\end{array}$ & $\begin{array}{l}\text { National FR } \\
\text { Local Authority FR } \\
\text { Village Land FR } \\
\text { Community FR } \\
\text { Private Forests }\end{array}$ & $\begin{array}{l}\text { Yes. Directly provided for in } \\
\text { village lands, indirectly options } \\
\text { exist in respect of transfer of } \\
\text { ownership of national and local } \\
\text { authority FR }\end{array}$ \\
\hline KENYA & $\begin{array}{l}\text { The Forests Act, Cap } 385 \text { [1962] } \\
\text { The Kenya Forest Policy, 1999 } \\
\text { Draft Forestry Bill, } 2000\end{array}$ & $\begin{array}{l}\text { State Forest } \\
\text { Local Authority Forest } \\
\text { Arboretum, Recreation Park, } \\
\text { Mini-Forest } \\
\text { Community Forests } \\
\text { Private Forest } \\
\text { Farm Forest }\end{array}$ & Yes, in respect of residual estates \\
\hline MALAWI & $\begin{array}{l}\text { National Forest Policy of Malawi, } \\
\text { January, } 1996 \\
\text { Forest Act, } 1997\end{array}$ & $\begin{array}{l}\text { Forest Reserve } \\
\text { Protected Forest Area } \\
\text { Village Forest Area }\end{array}$ & Yes, in Customary lands \\
\hline ZIMBABWE & $\begin{array}{l}\text { Forest Act, } 1948 \text { (amended 1996) } \\
\text { Communal Lands Forest Produce Act } \\
1987 \\
\text { Forest Policy for Tribal Trust Lands } \\
1968\end{array}$ & $\begin{array}{l}\text { Demarcated Forest } \\
\text { Nature Reserve } \\
\text { Private Protected Forest }\end{array}$ & No \\
\hline ZAMBIA & $\begin{array}{l}\text { The Forests Act, Cap. } 311 \\
\text { National Forestry Policy, } 1998 \\
\text { Forestry Bill, 1999 }\end{array}$ & $\begin{array}{l}\text { National Forest } \\
\text { Local Forest }\end{array}$ & $\begin{array}{l}\text { Yes, possible in respect of Local } \\
\text { Forests }\end{array}$ \\
\hline NAMIBIA & Forest Act, 1998 & $\begin{array}{l}\text { State FR } \\
\text { Regional FR } \\
\text { Forest Management Area } \\
\text { Nature Reserve } \\
\text { Community Forest }\end{array}$ & $\begin{array}{l}\text { Yes, in respect of Community } \\
\text { Forests }\end{array}$ \\
\hline SOUTH AFRICA & $\begin{array}{l}\text { National Forestry Policy, } 1996 \\
\text { Forestry Act, } 1998\end{array}$ & $\begin{array}{l}\text { State Forest } \\
\text { Provincial Reserve } \\
\text { Forest Nature Reserve } \\
\text { Forest Wilderness Area } \\
\text { Conservation Area } \\
\text { Private Forest } \\
\end{array}$ & $\begin{array}{l}\text { Yes, through restitution of State } \\
\text { Forests, which may be released to } \\
\text { state to manage. Also in respect of } \\
\text { communal land forests. }\end{array}$ \\
\hline SWAZILAND & $\begin{array}{l}\text { Private Forests Act, } 1961 \\
\text { Forest Preservation Act, } 1910 \\
\text { Natural Resources Act, } 1951 \\
\text { Preparation of New Forest Policy } \\
\text { underway }\end{array}$ & $\begin{array}{l}\text { Indigenous Forest } \\
\text { Private Forest }\end{array}$ & No \\
\hline MOZAMBIQUE & Forest \& Wildlife Act, 1999 & & $\begin{array}{l}\text { Yes, in principle in Reform Land } \\
\text { Act, } 1997 \text { and in F \& W Act, 1999, } \\
\text { but difficulties in working out } \\
\text { frameworks }\end{array}$ \\
\hline LESOTHO & $\begin{array}{l}\text { National Forestry Policy, } 1997 \\
\text { Forestry Act, } 1998\end{array}$ & $\begin{array}{l}\text { State FR } \\
\text { Private Forest } \\
\text { Community Forest } \\
\text { Co-operative Forest }\end{array}$ & $\begin{array}{l}\text { Yes; aim is to devolve as many } \\
\text { forests as possible to local level } \\
\text { ownership }\end{array}$ \\
\hline
\end{tabular}


In one sector in particular in East and Southern Africa, recognition of the importance of securing local common property in justiciable ways has emerged in recent years a need which has arguably been influential in the development of common property as a private group right in some countries. This is in respect of forests and woodlands, a massive resource in the region, amounting to at least 250 million hectares and representing sometime more than a third of the total land area in some states. ${ }^{39}$ The perceived value of this resource has risen commensurate with its loss over the last fifty years in particular, a loss which is variously calculated as in the region of three to ten million hectares annually. ${ }^{40}$

Over the last 75 years or so, the better quality forests and woodlands of East and Southern Africa has been steadily removed from local guardianship and tenure into Government-held property as variously Forest Reserves or Demarcated Forests. ${ }^{41}$ The purpose has been both economic [timber] and conservationary [mainly for water catchment and later for a wider range of biodiversity values], resting upon a longheld assumption that government is the only safe guardian for such valuable resources. The justification has been that ordinary rural citizens within whose sphere forests fall, do not have the tenurial incentive or basis through which they may be relied upon to demarcate or protect forest. As noted in more general reference to common properties, these resources have been steadfastly perceived as spheres of traditional access, not traditional tenurial interest. Until very recently, traditional mechanisms for holding and regulating the use of forests and woodlands have been ignored - and, as argued elsewhere - depressed the necessarily enhancement and development of these capacities to meet the demands of modern pressures, through ignoring their practice and potential [Alden Wily with Mbaya, op cit.].

Now, as has been the case throughout the world, the failure of states to sustainably secure the forests and woodlands they have co-opted is slowly forcing Governments to reconsider the potential role of forest-local communities in securing a sounder 'forest future' - the very sector of society from whom forest tenure and guardianship were so consistently and widely removed. ${ }^{42}$ So far, the role being identified for these often traditional owners is mainly in the sphere of management, with a slowly accruing range of state-people co-management regimes being provided for in new forest policy and law. Elsewhere I have explored the way in which many of these regimes in reality are designed more towards the sharing of forest product benefits with local communities than meaningful jurisdiction, the nomenclature of joint management notwithstanding. ${ }^{43}$ There are a growing number of countries however, where provision is being made for local communities to be designated as Manager of

\footnotetext{
39 Tanzania, Malawi, Zambia and Zimbabwe. Alden Wily with Mbaya provide details of the forest/woodland estate for each country, mainly based on figures provided in National Forest Policies.

Rates of forest loss range from $2.8 \%$ of the total area annually in Malawi [National Forest Policy, 1996] to $0.2 \%$ in South Africa [National Forestry Policy, 1996].

$41 \quad$ Alden Wily with Mbaya op cit. estimate that some 2,000 reserved Forests have been created. In East Africa alone these amount to nearly 20 million hectares with the greatest proportion in Tanzania [14.5 million ha].

There is a vast literature on this; refer Arnold, 1992 and 1999 for general reviews [but of mainly Asia] and FAO forthcoming for Africa.

Alden Wily with Mbaya, op cit.; Chapter Two, Alden Wily, 2000b.
} 
prime reserved estates, through agreement with the state [Lesotho, Tanzania, South Africa].

Of more direct interest to discussion here, there are also a slowly emerging number of states which are making policy and legal provision for forest-local communities to actually own forest and woodland. TABLE 3 summarises the case. In most states [Kenya, Namibia, Uganda, Malawi, Mozambique], this is being provided in reference to currently unreserved estates - those forests of mainly drier woodland types which have not been appropriated into state-owned reserves. These are in fact substantial, and in some countries account for the greater proportion of woody biomass. ${ }^{44}$ As the traditionally-viewed 'better' moist and montane forests dwindle, appreciation of the considerable values of woodlands grows.

Provision for the creation of Community Forests out of these as yet unreserved forest/woodlands is being made in new law. In one country in particular, Tanzania, implementation of this development is well advanced with some 500 or so Village Land Forest Reserves already declared. They have been created out of lands held in common and right up until the recent past, regarded as property available for the state to appropriate as needed [Alden Wily, 1999].

In a handful of states, opportunities are even being provided for forest-local communities to re-secure, on a case by case basis, forest/woodland already so appropriated and designated as Government-owned Forest Reserves. In Lesotho, the transfer of such estates has in fact been made policy and the procedures set out in new forest law. Elsewhere, the opportunity is obliquely provided, but nonetheless importantly exists [Tanzania]. In South Africa, there is full expectation in existing Land Policy [1994, 1997], Forest Policy [1996] and Forest law [1998], that the ownership of a significant number of State Forests will have to be returned to their original owners through the programme of restitution. The general thrust of strategy at this point in time is to encourage the community to re-lease the Forest back to the state forestry department for management purposes [Grundy, op cit.]. This has already been undertaken in one case and also in respect of wildlife range commons. ${ }^{45}$

\section{From open to closed access}

Of necessity, such developments promote the need in new land law to make provision for communities throughout the sub-continent to hold such properties in certified and legally-binding and useful ways. Tenure and, in this case, forest law, complement and reinforce each other. Overall fundamental transformation in the notion of common property is occurring. With recognition of recognition of customary tenure and integral to it, the capacity of groups and communities to hold property in discreet ways, the understanding of communal property itself is undergoing change. It is gaining character as owned and own-able estate, as capable of socio-spatial

$44 \quad$ National Forestry Policies variously cite the following proportions of forest/woodland as unreserved; Tanzania, 56.7\% [1998]; Uganda, 60\% [2000]; Zambia, 82\% [1998], Zimbabwe, 96\% [1999], Kenya, 56.7\% [1999].

45 Dwesa/Cwebe Forest Reserve in Eastern Cape Province, Grundy, 2000. The wildlife range case referred to is the Richtersveld Park, leased by local Nama owners to the National Parks Board; case described in Alden Wily with Mbaya, op cit. after P. van Sleight, 'Richtersveld Ask: What Happened to Our Daughter?' In Land \& Rural Digest, The Record of Rural People’s Policy, Vol. 1(2), 1998. 
definition as any other estate. In short, what was yesterday commonage, and with all the ills of open-access implied, is today private (group) property, the ownership of which may be recorded in land registers, documented in title deeds, and able to be upheld in the courts as private property. The potential for governments to appropriate such 'private' lands is truncated, and even where 'national' will to proceed overrides local will, such estates have by sleight of tenure law, shifted from classification as more or less un-owned land into private property, the expropriation of which is due proper compensation in law. To maintain the example of forest commons, slow but steady legal recognition of this is arising in the new processes offered for forest reserve creation in new forest law; it is, quite simply, no longer as easy for Governments to appropriate these properties

In this way, common property has come of age, modernised in the most logical way possible. The gain is to not just the millions of citizens from whom such estates have been routinely taken, or who have continued to hold commons in the most insecure of ways, but to the estates themselves, most of which, as observed earlier, remain just as unsuited to subdivision and individualisation in the $21^{\text {st }}$ century as they were in the $20^{\text {th }}$ and for which designation as national or state properties has proven less than successful.

And in the process, an unexpected if long-awaited development may well be coming to pass; property relations in the region in the $21^{\text {st }}$ century may well possess the very African character of customary relations which the $20^{\text {th }}$ century so determinedly denied. 


\title{
Cited References
}

\author{
[Refer laws in Tables].
}

Adams, M. 1999. Setbacks to Tenure Reform in the ex-Homelands of South Africa, in Oxfam GB, Land Rights in Africa, http://www.oxfam.org.uk/landrights/

Alden Wily, Liz. $\quad$ 1997. The Tenure and Control of Land Bill Uganda An appraisal of implications June 1997. British Development Division for East Africa, UK Department for International Development, Nairobi.

1998. Implications of the Uganda Land Bill [1998] for Customary Tenure. Paper presented to Conference on The Land Bill for Parliamentarians, funded by DFID and implemented by FOWODE, Kampala, April 24-25 1998. UK Department for International Development, Nairobi.

1999. Moving Forward in Community-Based Forest Management: The Tanzanian Way in Forest Action News, Vol.1 No. 1 1999. Forest Action Network for the Forests, Trees and People Programme in Eastern and Southern Africa, Nairobi.

2000a [forthcoming]. Changing Property Relations of State and People. A View of Land Reform in Eastern and Southern Africa [under publication consideration by Overseas Development Network, for a Natural Resources Perspective Series Publication].

2000b [forthcoming]. Communities and New Forest Law in Eastern and Southern Africa. [under publication consideration by UNASYLVA, FAO, Rome and International Forestry Review, Oxford].

2000c [forthcoming]. The Evolution of Community-Based Forest Management in Tanzania in FAO, 2000.

Alden Wily, Liz with Susan Mbaya. 2000 [forthcoming]. A Study of Land, People and Forests. A Critical Review of the Impact of Property Relations upon Community Involvement in the Management of Forests in Eastern and Southern Africa. IUCN with Natural Resources Institute, UK.

Alden Wily, Liz with K. Kabananukye. $\quad$ 1996. Pygmies in South Western Uganda The End of the Road - and the Beginning in No. 41996 Indigenous Affairs, J ournal of IWGIA Copenhagen

Arnold, J. 1992. Community Forestry Ten Years in Review. Community Forestry Note No. 7 Forests, Trees and People Programme. FAO, Rome.

FAO, Rome.

1998. Managing Forests as Common Property. FAO Forestry Paper No 136.

1999. Trends in Community Forestry in Review. First Draft. FAO, Rome.

Bruce, J., and Migot-Adholla, S. (eds.) 1994. Searching for Land Tenure Security in Africa The World Bank. Washington.

Carter, M.R., Wiebe, K.D., and Blarel, B. 1994. Tenure Security for Whom? Differential Effects of Land Policy in Kenya' in Kenya in Searching for Land Tenure Security in Africa, Bruce, J. and MigotAdholla, S. (eds.).

Coulmin, C. and J. Quan [eds.]. 2000 [forthcoming] Evolving Land Rights, Policy and Tenure in Africa. IIED \& NRI, London.

Deininger, K. and Binswanger, H. 1999. The Evolution of the World Bank's Land Policy in The World Bank Research Observer Volume 14 No. 2 August 1999. Washington. The World Bank. 
Dessalegn, Rahmato, D.

2000 [forthcoming]. Land and Rural Poverty in Ethiopia in Toulmin \& Quan [eds].

DLA [Department of Land Affairs] 1999. Review of the Land Reform Support Programme for DFID, EU and Danida. Mclntosh, A. \& J. Barnard, Gwendoyn Wellman, Anne Vaughan, S. Sejake, L. Cliffe, R. Palmer. Pretoria. Mclntosh, A., Barnard, J. Wellman, Gwendolyn, Vaughan, Anne, Sejake, S. Cliffe, L. and Robin Palmer.

2000. Policy Statement by Minister for Agricultural and Land on New Policy Directions in Land Matters. Pretoria, South Africa

FAO 2000. Proceedings of the International Workshop on Community Forestry in Africa. Participatory Forest Management. A Strategy for Sustainable Forest Management in Africa. 26-30 April, 1999. Banjul, The Gambia. Rome.

Government of Uganda. 1999. Report on the Land Act Implementation Study. Ministry of Water, Lands and Environment, Kampala.

Government of Zimbabwe. 1998. National Land Policy Framework Paper [Discussion Paper]. Ministry of Lands and Agriculture, with FAO. November 1998, Harare.

Grundy, Isla. 2000. Land Rights and Community Management of Forest Resources in South Africa, in Alden Wily with Mbaya, 2000.

Hanby, Jeanette 1999. The Tenure Status of Hadzabe in Northern Tanzania at the Beginning of the $21^{\text {st }}$ Century. Submission to Survival I nternational, UK.

Kasanga, K. 1999 Land Policy and Management in Lesotho, (GTZ) Land Tenure Development in Developing Countries Sector Project, Maseru.

Kloeck-Jenson, S $\quad 1997 \quad$ Analysis of the Parliamentary Debate and New National Land Law for Mozambique. Land Tenure Centre Project-Mozambique September 1997

Kloeck-Jenson, S., Bruce, J. and Susana Lastarria-Cornhiel. 1998. Analysis of the July 1998 Draft Regulations for the Land Law in Mozambique: A Need for More Specificity. Land Tenure Center, Maputo.

Luling, Virginia. $\quad 1998$ Visit to the Central Kalahari Game Reserve in June 1998. Report.

Survival International. London

Luling, Virginia and J. Kenrick 1998. Forest Foragers of Tropical Africa A Dossier on the Present Condition of the 'Pygmy' Peoples Survival International, London.

Maletsky, C. Articles in The Namibian Newspaper: $9^{\text {th }}, 18^{\text {th }}$, February, and $11^{\text {th }}$ February, 2000. Windhoek, Namibia.

McAuslan, P. 2000. [forthcoming] Only the Name of the Country Changes: The Diaspora of 'European' Land Law in Commonwealth Africa (with special reference to English land law) in DFID, 2000 in Toulmin, Camilla. \& J. Quan [eds.]

Migot-Adholla, S.E., Place, F., and Oluoch-Kosura, W. 1994. Security of Tenure and Land Productivity in Kenya in Bruce, J. and Migot-Adholla, S. (eds.).

Mushove, P. 2000. Local Community Participation in the Management of Communal Woodlands in Northern Mozambique in Alden Wily with Mbaya, 2000.

Mustafa, K. 1997. Eviction of Pastoralists from the Mkomazi Game Reserve in Tanzania: An Historical Review. Pastoral Land Tenure Series. No. 8 International Institute for Environment and Development, London. 
Ng'ong'ola, C. $\quad$ 1997. Land Rights for Marginalized Ethnic Groups in Botswana with Special Reference to the Basarwa. In Jounral of African Law, 41:1-26. School of Oriental and African Studies, London.

Niamir-Fuller, Maryam, S. Lugando, T. Kundy and edited by K. Mustafa. 1994. Barabaig Displacement from Hanang District to the Usangu Plains: Changes in Natural Resource Management and Pastoral Production in Tanzania. IIED, London.

Ntsebeza, L. $\quad$ 1999. Land Tenure Reform in South Africa: An example from the eastern Cap Province. Issue Paper No. 82. IIED, London.

Palmer, R. $\quad 2000 \quad$ [forthcoming]. Land Policy in Africa: Lessons from Recent Policy and Implementation Processes. Chapter 14 in Coulmin \& Quan [eds.].

Platteau, J-P. 1992. Land reform and structural adjustment in sub-Saharan Africa: controversies and guidelines. FAO Economic and Social Development Paper. No. 107. Rome, FAO.

Roth, M. and J. Cochrane and W. Kisamba-Mugerwa. 1994. Tenure Security, Credit Use and Farm Investment in the Rujubura Pilot Land Registration Scheme, Uganda. In Searching for Land Tenure Security in Africa. J. Bruce and S. Migot-Adholla [eds.]. The World Bank.

Roth, M., Unruh, J., and Barrows, R. 1994 Land Registration, Tenure security, Credit Use, and Investment in the Shebelle Region of Somalia. Chapter 9 in Bruce \& Migot-Adholla [eds.].

Shazali, S. \& Ahmed, A.G. B. $\quad$ 2000. 'Pastoral Land Tenure and Agricultural Expansion: Sudan and the Horn of Africa. IIED Dryland Programme Issue Paper No. 85 J une 1999.

Shipton, P. 1989. Land and the Limits of Individualism: Population Growth and Tenure Reform South of the Sahara. Development Discussion Papers Harvard Institute for International Development, Boston.

Shivji, I. \& W. Kapinga. 1997. Implications of the Draft Bill for the Land Act in Change Vol. 5 First Quarter, 1997, Dar es Salaam.

Toulmin, Camilla \& J. Quan [eds.]. 2000 [forthcoming].] Evolving Land Rights, Policy and Tenure in Africa, IIED \& NRI, UK.

Van den Brink. R. 2000. Zimbabwe Land Reform Update, March 2, 2000. The World Bank, Washington.

White, $\mathrm{R}$

1998. Land Issues and Land Reform in Botswana Chapter One in ZERORegional Environment Organization.Enhancing Land Reforms in Southern Africa: Review on Land Reform Strategies and Community Based Natural Resources Management. Harare, Zimbabwe. 